\title{
Nanofilled Antifriction Polymeric Composite Materials for Parts of Friction Units of Sea and River Transport
}

\author{
A.V. Buketov ${ }^{1, *}$, M.V. Brailo', O.O. Sapronov ${ }^{1}$, D.G. Kruglyj ${ }^{1}$, \\ E.S. Appazov ${ }^{1}$, L. Dulebová ${ }^{2}$ K.M. Klevtsov ${ }^{1}$
}

${ }^{1}$ Kherson State Maritime Academy, 20, Ushakov Ave., 73003 Kherson, Ukraine

2 Technical University of Košice, 1/9, Letná St., 04001 Košice, Slovak Republic

(Received 15 July 2020; revised manuscript received 15 October 2020; published online 25 October 2020)

\begin{abstract}
The tribological properties of epoxy-composite materials filled with nano- and microdispersed particles and thermoplastic under the influence of the environment of seawater have been analyzed. It has been found that the composition of the material, friction conditions and the marine environment significantly affect the tribological properties of composites. The tribological properties of the developed epoxy matrix, which contains two different hardeners, have been studied. Improvement of the tribological properties of composites with the introduction of nanographite and pearlite particles into their composition has been proved. A method for improving the antifriction properties of polymer composite materials by combining a thermoset matrix filled with nano- and dispersed particles with thermoplastic granules has been proposed. It is proved that the tribological properties of epoxy-composite thermosetting plastics have been improved by adding granules of a thermoplastic filler called PA-6 polyamide into their composition during friction under the influence of seawater. On the basis of the obtained research results, the assumptions of the mechanism of wear of epoxy composites with a two-component bidispersed filler have been suggested. To confirm the results obtained, the study of the surface roughness of the composites in the contact area after friction testing using a profilometer, as well as an optical method, has been conducted. Recommendations are given for the use of the developed composite with thermoplastic granules for the manufacture of sliding bearings.
\end{abstract}

Keywords: Friction, Tribological properties, Epoxy composite, Sea and river transport.

DOI: $10.21272 /$ jnep.12(5).05025

PACS number: 82.35. $-\mathrm{x}$

\section{INTRODUCTION}

Most of the known polymer composites used in friction units have relatively low strength, heat resistance, wear resistance and are characterized by high values of thermal expansion [1]. Therefore, it is necessary to create an antifriction polymer composite material with enhanced physical, mechanical and thermophysical properties [2, 3].

Parts and units of sea and river transport are exposed to different types of wear. That is why it is reasonable to search for fillers that can provide optimal properties of composites, in particular [4-6]:

- lower coefficient of friction;

- increased resistance to wear when interacting with abrasive particles;

- resistance to dry slip friction;

- wear resistance in the lubricating environment.

Such problems can be solved using disperse solid lubricating particles [7,8], which, in addition to acting as a filler of the composite, provide solid lubrication in the tribo-contact zone in the case of insufficiency or complete absence of a lubricating medium.

There are many works dedicated to this problem $[9,10]$, which are aimed mainly at finding the optimal types of fillers (graphite, molybdenum disulfide, boron nitride, etc.) capable of providing a reduction in the coefficient of friction between the contact surfaces of the friction pair, in particular, due to the optimization of the surface contact at the macro level. This effect is achieved by optimizing the shape and size of these fill- ers, leading to a positive macro effect. The work of F.X. Borras et al. [11], which considers the methods for improving the tribological properties of composite materials (CMs) used in stern tube systems of ships, is very important.

However, it should be noted that relatively few works are dedicated to the comparative analysis of the impact of solid lubricating particles of the filler on various types of wear $[12,13]$. Therefore, an in-depth study of this problem, in particular, the structure, mechanical properties, patterns of wear in the conditions inherent in marine transport systems, is an urgent task.

The objective of this work is to develop epoxy composites with enhanced wear resistance for parts and mechanisms that are operated in friction units, including stern tube systems of ships.

\section{MATERIALS AND METHODS}

To study the tribological properties, a previously developed matrix was used, in particular, a matrix based on epoxy resin CHS-Epoxy 525 ( $q=100$ pts. wt.) and hardeners PEPA + Telalit $410\left(q_{1}+q_{2}=5+5\right.$ pts. wt. $)$. The matrix was formed at a temperature of $T=433 \mathrm{~K}$.

CHS-Epoxy 525 (Spolchemie, Ústí nad Labem, Czech Republic) is a low molecular weight epoxy oligomer that does not have modifiers and is an analogue of the epoxy diane oligomer ED-20 (ISO 18280:2010).

PEPA is a polyethylene polyamine hardener (TU 6-05-241-202-78) for cross-linking epoxy compositions.

Telalit 410 (Spolchemie, Ústí nad Labem, Czech

\footnotetext{
*buketov.andrey@gmail.com
} 
Republic) is a modified amine adduct hardener based on aliphatic polyamine.

Nanographite powder HW Nano C963 (China) with a particle size of 80-100 nm. (CAS Number: 7782-42-5). The graphite percentage is $99.95 \%$.

Perlite is a material obtained as a result of thermal treatment of an aqueous aluminosilicate perlite rock of volcanic origin. The chemical composition of perlite according to GOST 25226-96 is as follows: silicon oxide $\left(\mathrm{SiO}_{2}\right)-65-77 \%$, aluminum oxide $\left(\mathrm{Al}_{2} \mathrm{O}_{3}\right)-11-16 \%$, iron oxide $\left(\mathrm{FeO}+\mathrm{Fe}_{2} \mathrm{O}_{3}\right)-0.5-6.0 \%$, oxide calcium $(\mathrm{CaO})$ $-0.1-3.5 \%$, potassium and sodium oxide $\left(\mathrm{K}_{2} \mathrm{O}+\mathrm{Na}_{2} \mathrm{O}\right)$ $-3-10 \%$.

Granules of thermoplastic filler called PA-6 polyamide (OST 06-C9-93) were added to the above materials. The granules in the amount of $q=30 \mathrm{pts}$. wt. and $q=60$ pts. wt. were placed in such a way that their lateral surface was turned to the friction region. Dimensions of granules are: diameter $d=3.2 \pm 0.1 \mathrm{~mm}$, length $l=3.5 \pm 0.1 \mathrm{~mm}$.

CMs were formed from dispersed particles and polyamide granules (provided they were located with their lateral surface (LS) turned to the contact region) of the following composition:

- $\quad$ NGP (HW Nano C963 + perlite);

- NGPP (HW Nano C963 + perlite + polyamide).

The developed CMs based on two-component bidisperse fillers of the following composition were used (Table 1).

Table 1 - Composite materials studied in the work

\begin{tabular}{|c|c|c|c|c|c|c|c|}
\hline 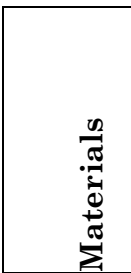 & 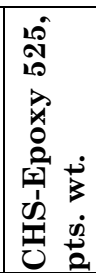 & $\begin{array}{l}\dot{2} \\
\dot{3} \\
\dot{0} \\
\frac{0}{2} \\
\dot{4} \\
\frac{1}{0} \\
\frac{1}{2}\end{array}$ & 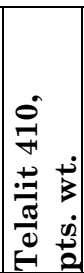 & 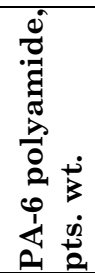 & 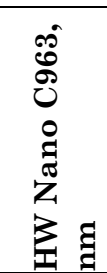 & 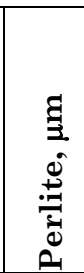 & 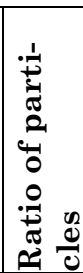 \\
\hline Matrix & 100 & 5 & 5 & - & - & - & - \\
\hline NGP & 100 & 5 & 5 & - & $80-100$ & $5-10$ & $6 / 20$ \\
\hline \begin{tabular}{|l|} 
NGPP-1 \\
\end{tabular} & 100 & 5 & 5 & 30 & $80-100$ & $5-10$ & $6 / 20$ \\
\hline NGPP-2 & 100 & 5 & 5 & 60 & $80-100$ & $5-10$ & $6 / 20$ \\
\hline
\end{tabular}

It should be noted that an overhead conductor was used to control the placement of granules with their lateral or end surface turned to the zone of contact with the counterbody during the formation of epoxy composites. Their number was controlled as well. This made it possible to distribute the granules evenly in the matrix material and to ensure the uniformity of their location.

The tribological properties of materials were studied on a serial production machine 2070 SMT-1 (Zapadpribor, Moscow, Russia) according to the block on ring technique (ASTM G77-17). Dimensions of the friction pair elements: the counterbody diameter is $50 \mathrm{~mm}$, the upper radius of the specimen is $34 \mathrm{~mm}$, the counterbody width is $12 \mathrm{~mm}$, and that of the specimen is $10 \mathrm{~mm}$. The friction area of the specimen was $200 \mathrm{~mm}^{2}$.

The disk (counterbody) was made of steel 45 heattreated to a hardness of 45-48 HRC and a surface roughness $R_{a}=0.16-0.32 \mu \mathrm{m}$.

The studies were conducted in seawater (35\%) at a specific load $p=2.7 \mathrm{MPa}$ and a sliding speed $v=0.5 \mathrm{~m} / \mathrm{s}$ and $v=1.0 \mathrm{~m} / \mathrm{s}$. The friction path of specimens during tests was $10000 \mathrm{~m}$ (at $v=0.5 \mathrm{~m} / \mathrm{s}$ ) and $20000 \mathrm{~m}$ (at $v=1.0 \mathrm{~m} / \mathrm{s})$.

The temperature of the test specimens was measured by a "chromel-kopel" thermocouple (Electro Radio Group, Krivoy Rog, Ukraine), the signal from which was recorded by measurement equipment. The end of the thermocouple was crocheted at a distance $l=2 \mathrm{~mm}$ from the contact area of the specimen with the counterbody.

The test modes were selected taking into account the operating conditions of the CM. The mass of specimens was determined by weighing with an accuracy of $\pm 0.001 \mathrm{~g}$.

The quality of the surface of the experimental specimens after testing was evaluated using a profilometer of the model 296 according to the parameter $R_{a}$ (GOST 2789-73). In addition, the workplace of measuring microgeometry is equipped with a digital oscilloscope IRIS Waveware.

After the tests, the structure of the $\mathrm{CM}$ after friction was investigated on the XJL-17AT metallographic microscope (Wuzhou New Found Instrument Co., Ltd., Guangxi, China), which was equipped with a Levenhuk C310 NG (3.2 MegaPixels) camera (Levenhuk, Inc., Tampa, FL), with a magnification of $\times 200$ times.

The materials were solidified according to the predetermined regimen [14].

\section{RESULTS AND DISCUSSION}

At the first stage, the tribological properties of friction in seawater conditions of the matrix and NGP materials were investigated. The results are shown in Fig. 1 and Table 2. It was established experimentally that the tribological properties of the matrix differ insignificantly when the sliding speed increases from $v=0.5 \mathrm{~m} / \mathrm{s}$ (Fig. 1a) to $v=1.0 \mathrm{~m} / \mathrm{s}$ (Fig. 1b). The coefficient of friction was $f=0.175-0.190$, and the mass wear rate was $I_{m}=0.3-0.5 \mathrm{mg} / \mathrm{km}$ (Table 2). At the same time, the temperature tends to increase from $T=305-307 \mathrm{~K}$ (at $v=0.5 \mathrm{~m} / \mathrm{s}$ ) to $T=314-316 \mathrm{~K}($ at $v=1.0 \mathrm{~m} / \mathrm{s}$ ), and the lapping path also increases from $l=3900-4200 \mathrm{~m}$ to $l=6600-7100 \mathrm{~m}$

The aggressive environment influences the tribological characteristics of the specimens. Seawater, in comparison with air, lowers the temperature of the tribocouple at a sliding speed $v=0.5 \mathrm{~m} / \mathrm{s}$. At the same time, the release of heat during friction decreases, which reduces the length of the lapping path. Moreover, an oxide film is formed on the surface of the counterbody, which leads to an improvement in the indices of tribological properties due to work in the seawater environment [15].

The deterioration dynamics of tribological properties with an increase in the sliding speed was observed in the material based on epoxy matrix and two-component bidisperse filler NGP (Fig. 1c, d). In particular, an increase in the friction coefficient from $f=0.070$ $0.075($ at $v=0.5 \mathrm{~m} / \mathrm{s})$ to $f=0.230-0.240($ at $v=1.0 \mathrm{~m} / \mathrm{s})$ and the friction moment from $M=0.9-1.0 \mathrm{~N} \cdot \mathrm{m}$ to $M=2.9-3.0 \mathrm{~N} \cdot \mathrm{m}$ was observed for the NGP material. At the same time, the mass wear rate decreased from $I_{m}=0.20-0.30 \mathrm{mg} / \mathrm{km}$ to $I_{m}=0.05-0.07 \mathrm{mg} / \mathrm{km}$ (Table 2). Whereas the temperature remained practically unchanged in the range $T=303-308 \mathrm{~K}$, however, the lapping path increased from $l=4500-5000 \mathrm{~m}$ to $l=9100$ - 
$10000 \mathrm{~m}$ with an increase in the sliding speed from $v=0.5 \mathrm{~m} / \mathrm{s}$ to $v=1.0 \mathrm{~m} / \mathrm{s}$. In our opinion, the results obtained can be explained by the fact that at the initial stage, microroughness is cut off, and the surface of the specimens is smoothed out in the contact zone. This leads to an intensive decrease in the friction coefficient to $f=0.020-0.060$ (investigation path $l=(4-6) \cdot 10^{3} \mathrm{~m}$ ). At the same time, the aggressive medium interacts

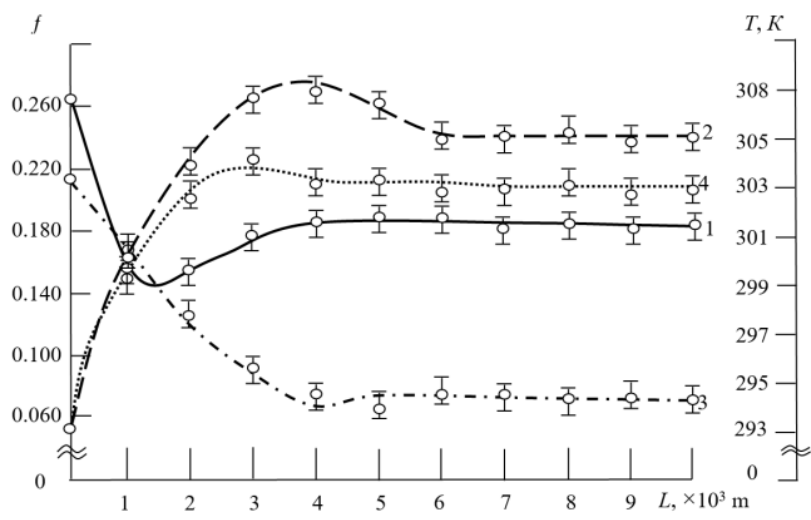

with the studied material due to transferring the liquid to the contact zone with the counterbody. Such interaction of the material with the aggressive medium causes the adsorption of water by the specimen surface. In particular, seawater molecules penetrate into the epoxy matrix, the surface of the composite swells, which leads to an increase in the coefficient of friction and in the lapping path, accordingly.

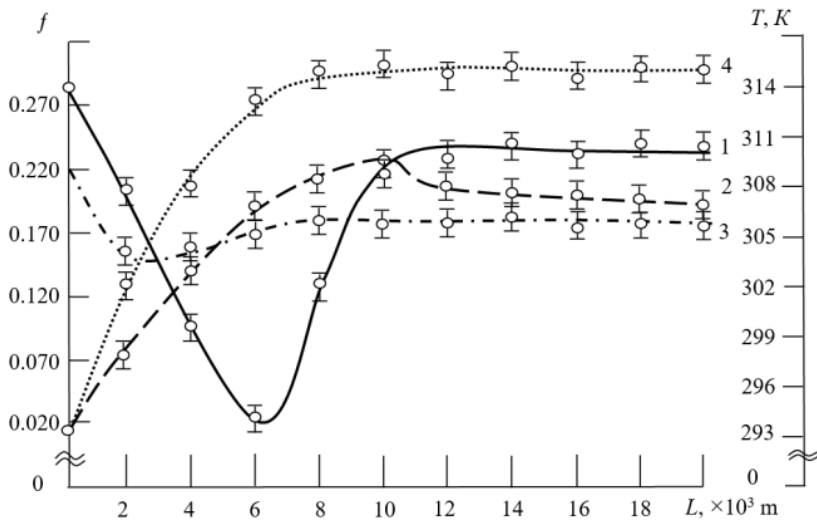

$\mathrm{b}$

Fig. 1 - Dependence of the coefficient of friction $(1,3)$ and temperature in the zone of friction $(2,4)$ on the test path of materials at a sliding speed (a) $v=0.5 \mathrm{~m} / \mathrm{s}$ and (b) $v=1.0 \mathrm{~m} / \mathrm{s}: 1,2-$ matrix; $3,4-\mathrm{NGP}$

Table 2 - Tribological properties of NGP material

\begin{tabular}{|l|c|c|c|c|}
\hline \multirow{2}{*}{ Parameters } & \multicolumn{4}{|c|}{ Materials } \\
\cline { 2 - 5 } & \multicolumn{2}{|c|}{ Matrix } & \multicolumn{2}{c|}{ NGP } \\
\cline { 2 - 5 } & $v=0.5 \mathrm{~m} / \mathrm{s}$ & $v=1.0 \mathrm{~m} / \mathrm{s}$ & $v=0.5 \mathrm{~m} / \mathrm{s}$ & $v=1.0 \mathrm{~m} / \mathrm{s}$ \\
\hline $\begin{array}{l}\text { Coefficient of } \\
\text { friction, } f\end{array}$ & $\begin{array}{c}0.180- \\
0.190\end{array}$ & $\begin{array}{c}0.175- \\
0.180\end{array}$ & $\begin{array}{c}0.070- \\
0.075\end{array}$ & $\begin{array}{c}0.230- \\
0.240\end{array}$ \\
\hline $\begin{array}{l}\text { Temperature } \\
T, \mathrm{~K}\end{array}$ & $305-307$ & $314-316$ & $303-305$ & $306-308$ \\
\hline $\begin{array}{l}\text { Lapping path } \\
l, \mathrm{~m}\end{array}$ & $3900-4200$ & $6600-7100$ & $4500-5000$ & $\begin{array}{c}9100- \\
10000\end{array}$ \\
\hline $\begin{array}{l}\text { Mass wear } \\
\text { rate } I_{m}, \mathrm{mg} / \mathrm{km}\end{array}$ & $0.40-0.50$ & $0.30-0.40$ & $0.20-0.30$ & $0.05-0.07$ \\
\hline
\end{tabular}

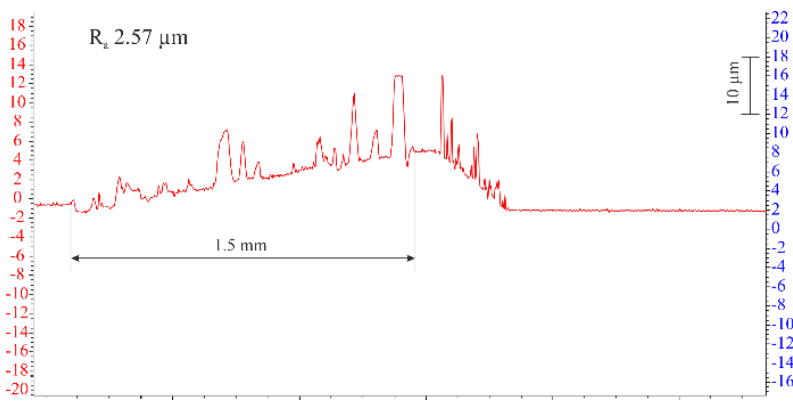

a
Further, to confirm the results, profilograms of the surface in the contact area were examined after friction testing of CMs. From the obtained profilogram of the matrix it is noticeable that with increasing test rate of the specimen to $v=1.0 \mathrm{~m} / \mathrm{s}$, the roughness decreases to $R_{\mathrm{a}}=2.57 \mu \mathrm{m}$, with the maximum height of elevations on the surface of the specimen of $12-14 \mu \mathrm{m}$ (Fig. 2a). The value of the wear rate with increasing rate of testing the material is lower, as well as the coefficient of friction as shown in Table 2. It is noticeable that the roughness decreases and its values are $R_{\mathrm{a}}=1.44 \mu \mathrm{m}$ and $R_{\mathrm{a}}=1.25 \mu \mathrm{m}$, respectively, at the investigation of the

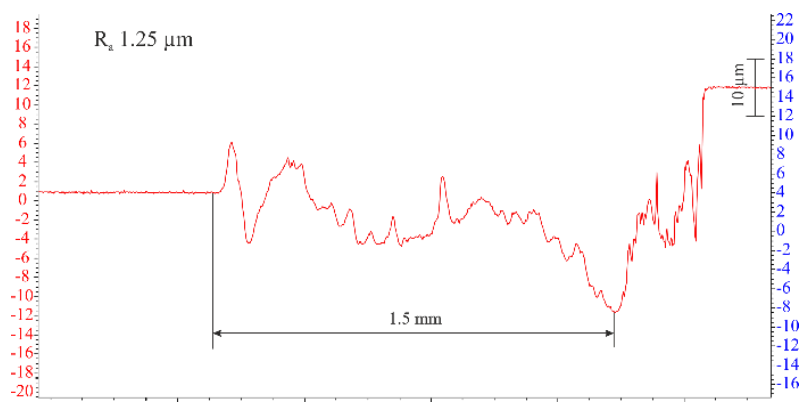

$\mathrm{b}$

Fig. 2 - The profilograms of the surface in the contact area after friction testing at friction rate $v=1.0 \mathrm{~m} / \mathrm{s}$ : (a) matrix; (b) NGP material

surface of the specimen of a particle-filled NGP at rates $v=0.5 \mathrm{~m} / \mathrm{s}$ and $v=1.0 \mathrm{~m} / \mathrm{s}$ (Fig. $2 \mathrm{~b}$ ).

At the next stage, the friction surface of materials was investigated using the optical microscopy method (Fig. 3). It was found that the matrix surface investigated at the sliding speed $v=0.5 \mathrm{~m} / \mathrm{s}$ is covered with microirregularities, scratches and scoring. This indicates an increase in the friction coefficient and an increased wear of the material (Fig. 3a). At the same time, the cause of the non-uniformity in the traces of wear is the formation of an oxidation film on the surface of the counterbody, which makes it possible to improve the properties of tribocouples [16]. In turn, photos of the friction surface of the matrix investigated at the sliding speed $v=1.0 \mathrm{~m} / \mathrm{s}$ (Fig. 3b) show the lines distributed uniformly parallel to the rotation of the counterbody along the surface of fric- 
tion. In addition, scars are visible on the surface.

A similar tendency was observed in the fracture images of the NGP materials (Fig. 3c, d). Friction lines

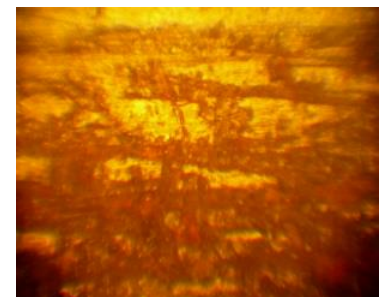

a

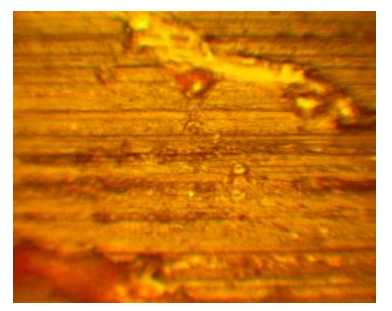

$\mathrm{b}$

contain slightly noticeable depressions, which is consistent with the assumption of the presence of an oxidation film in friction.

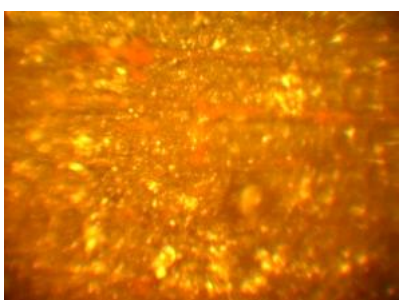

c

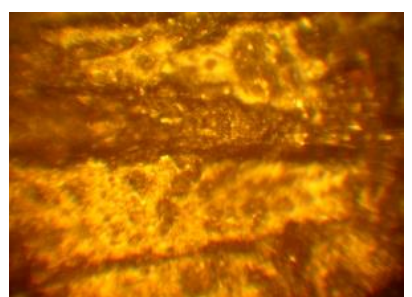

d

Fig. 3 - Surface view in the contact zone after frictional testing of the following materials with a magnification of $200 \times$ : (a) matrix $(v=0.5 \mathrm{~m} / \mathrm{s})$; (b) matrix $(v=\mathrm{v} 1.0 \mathrm{~m} / \mathrm{s})$; (c) NGP material $(v=0.5 \mathrm{~m} / \mathrm{s})$; (d) NGP material $(v=1.0 \mathrm{~m} / \mathrm{s})$

At the next stage, the tribological properties of the NGPP material with PA-6 granules at the content of $q=30$ pts. wt. (NGPP-1) and $q=60$ pts. wt. (NGPP-2) in seawater conditions (Table 3 ) were investigated.

It was determined that the NGPP-1 material acquires better tribological properties with an increase in the sliding speed from $v=0.5 \mathrm{~m} / \mathrm{s}$ to $v=1.0 \mathrm{~m} / \mathrm{s}$ as shown in Table 3. The friction coefficient, the mass wear rate and lapping path decrease from 0.145-0.155 to $0.038-0.045$, from $0.60-0.70 \mathrm{mg} / \mathrm{km}$ to 0.05 $0.07 \mathrm{mg} / \mathrm{km}$ and from $4600-5000 \mathrm{~m}$ to $2400-2800 \mathrm{~m}$, respectively. The temperature is practically unchanged (303-305 K) in this case.

For the NGPP-2 material (Table 3), the coefficient and moment of friction are close to the analogous values of the NGPP-1 material. In this case, the coefficient of friction is $0.065-0.092$, the mass wear rate is 0.20 $0.60 \mathrm{mg} / \mathrm{km}$, the lapping path is $2600-7200 \mathrm{~m}$, the temperature is $302-306 \mathrm{~K}$. However, the NGPP-1 material with the sliding speed $v=1.0 \mathrm{~m} / \mathrm{s}$ is characterized by the maximum improvement in the wear rate and lapping path.

Table 3 - Tribological properties of the NGPP materials

\begin{tabular}{|c|c|c|c|c|c|c|}
\hline \multirow{3}{*}{ Parameters } & \multicolumn{6}{|c|}{ Materials } \\
\hline & \multicolumn{2}{|c|}{ NGP } & \multicolumn{2}{|c|}{$\begin{array}{c}\text { NGPP-1 } \\
(q=30 \text { pts. } \text { wt. })\end{array}$} & \multicolumn{2}{|c|}{$\begin{array}{c}\text { NGPP-2 } \\
(q=60 \text { pts. wt. })\end{array}$} \\
\hline & $v=0.5 \mathrm{~m} / \mathrm{s}$ & $v=1.0 \mathrm{~m} / \mathrm{s}$ & $v=0.5 \mathrm{~m} / \mathrm{s}$ & $v=1.0 \mathrm{~m} / \mathrm{s}$ & $v=0.5 \mathrm{~m} / \mathrm{s}$ & $v=1.0 \mathrm{~m} / \mathrm{s}$ \\
\hline Coefficient of friction, $f$ & $0.070-0.075$ & $0.230-0.240$ & $0.145-0.155$ & $0.038-0.045$ & $0.065-0.075$ & $0.089-0.092$ \\
\hline Temperature $T, \mathrm{~K}$ & $303-305$ & $306-308$ & 304-305 & $303-304$ & $302-303$ & 304-306 \\
\hline Lapping path $l, \mathrm{~m}$ & $4500-5000$ & $9100-10000$ & $4600-5000$ & $2400-2800$ & $2600-3000$ & $6800-7200$ \\
\hline Mass wear rate $I_{m}, \mathrm{mg} / \mathrm{km}$ & $0.20-0.30$ & $0.05-0.07$ & $0.60-0.70$ & $0.05-0.07$ & $0.50-0.60$ & $0.20-0.30$ \\
\hline
\end{tabular}

By the method of the profilometric analysis of the surface of materials, it was found that the surface roughness of specimens filled with NGPP particles decreases with increasing sliding speed (Fig. 4). It was found that there are friction tracks on all specimens. The NGPP-1 material has the minimum surface roughness $R_{\mathrm{a}}=0.83 \mu \mathrm{m}$ at the sliding speed of $v=1.0 \mathrm{~m} / \mathrm{s}$. Consequently, a decrease in the roughness indicates

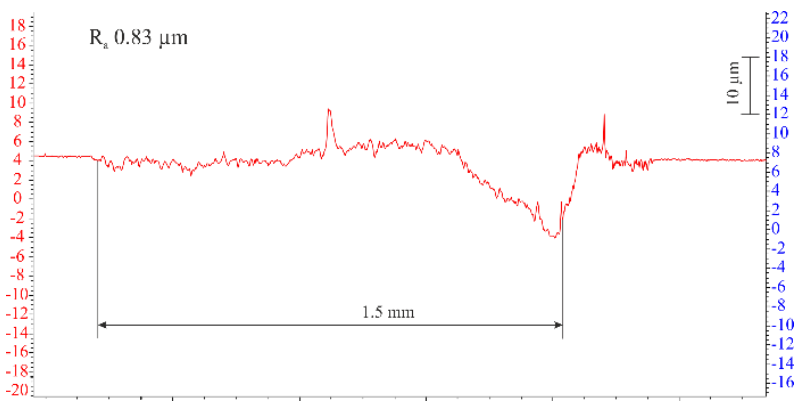

a that under the given conditions and the content of the fillers, the maximum lapping in the "specimen-counterbody" pair is carried out in the matrix. The obtained results are consistent with the tribological characteristics of this material.

The above physical regularities are confirmed by optical microscopy (Fig. 5). When analyzing the images of friction surfaces, it can be stated that all the images

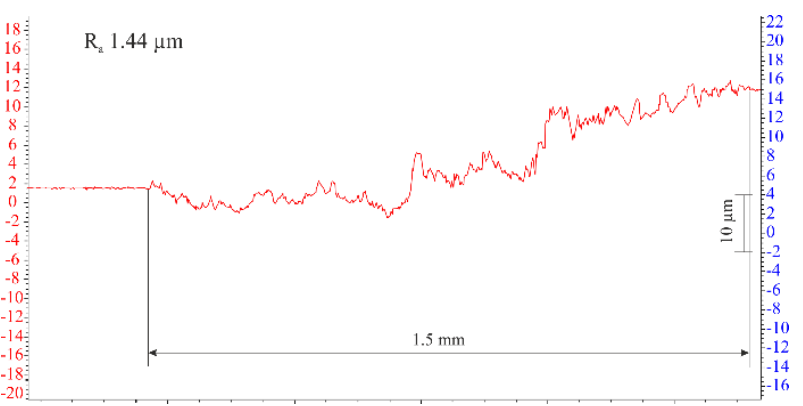

$\mathrm{b}$

Fig. 4 - The profilograms of the surface in the contact area after friction testing of the NGPP materials at friction rate $v=1.0 \mathrm{~m} / \mathrm{s}$ : (a) NGPP-1; (b) NGPP-2 
show pronounced friction paths, as well as scuffing and scratches on the surface of materials. Such depressions testify to an intensive wear of materials under the influence of abrasive. At the same time, it should be noted that friction paths without noticeable depressions were observed on the friction surface of NGPP-1 material at the sliding speed $v=0.5 \mathrm{~m} / \mathrm{s}$ (Fig. $5 \mathrm{a}, \mathrm{b})$, which

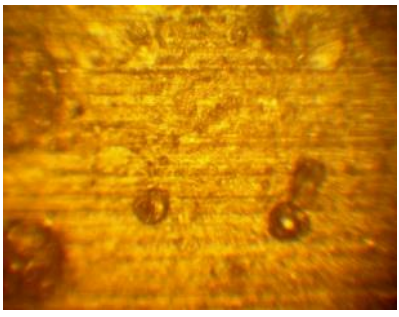

a

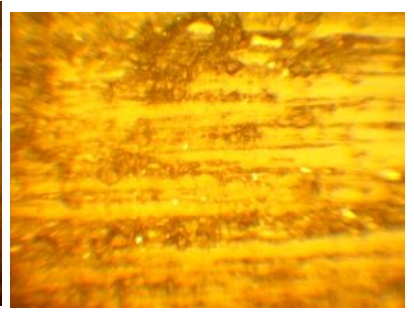

$\mathrm{b}$ corresponds to the obtained profilogram (Fig. 4). It is shown that the tracks formed during friction are filled with a third body. Obviously, particles of both dispersed filler and counterbody were observed in the contact zone during friction. This confirms the results of tribological studies of materials.
Fig. 5 - Surface view of NGPP materials in the contact zone after frictional testing of materials with a magnification of $\times 200$ : (a) NGPP-1, $v=0.5 \mathrm{~m} / \mathrm{s}$; (b) NGPP-1, $v=1.0 \mathrm{~m} / \mathrm{s}$; (c) NGPP-2, $v=0.5 \mathrm{~m} / \mathrm{s}$; (d) NGPP-2, $v=1.0 \mathrm{~m} / \mathrm{s}$
Based on the work of scientists in this area J.B. Chen [17, 18], Z. Wang [19], it is known that the composition of seawater includes $\mathrm{Ca}^{2+}$ and $\mathrm{Mg}^{2+}$ in the forms of $\mathrm{CaCO}_{3}$ and $\mathrm{Mg}(\mathrm{OH})_{2}$, which significantly affects the friction surface of materials. At the same time, in the work [19], it was confirmed that frictional contact surfaces are rubbed and the elevations are destroyed, in this case small wear products are grinded and purified from the polymer matrix. Subsequently, these parts of antifriction materials fall into a solution of seawater. As a result, scientists claim that fragments of polymeric materials and seawater create a suspension liquid that has a sufficiently high lubricating effect and prevents direct contact between rubbing surfaces. When analyzing the results of studies of the friction coefficient, wear rate, lapping path, profilograms and images of the friction surfaces of CMs based on epoxy resin and fillers, the theory of scientists about the effect of seawater on polymer material during the friction was confirmed.

\section{CONCLUSIONS}

The main regularities in the effect of seawater on the tribological properties of $\mathrm{CMs}$ have been established. In particular, it is shown that the matrix (epoxy resin CHS-Epoxy 525 ( $q=100$ pts. wt.) and hardeners PEPA + Telalit $410\left(q_{1}+q_{2}=5+5\right.$ pts. wt. $)$ have lower tribological properties at friction in seawater compared with the properties at dry friction. An increase in the sliding speed practically does not affect wear resistance. At a sliding speed from $v=0.5 \mathrm{~m} / \mathrm{s}$, the friction coefficient was $f=0.175-0.190$, the mass wear rate was $I_{m}=0.3-0.5 \mathrm{mg} / \mathrm{km}$, the temperature was $T=305$ $316 \mathrm{~K}$, and the lapping path of the material was $l=3900-7100 \mathrm{~m}$.

It was found that the NGP material at a sliding wear rate, and the NGP material at a sliding speed $v=0.5 \mathrm{~m} / \mathrm{s}$ has the lowest friction coefficient $f=0.070$ 0.075 and friction moment $M=0.9-1.0 \mathrm{~N} \cdot \mathrm{m}$ with lapping path $l=4500-5000 \mathrm{~m}$.

It was established that the NGPP-1 material is characterized by the best values of the tribological properties and surface roughness at a sliding speed of $1.0 \mathrm{~m} / \mathrm{s}$. It has the smallest value of the friction coefficient $f=0.038-0.045$, the wear rate is $I_{m}=0.05$ $0.07 \mathrm{mg} / \mathrm{km}$, the lapping path is $l=2400-2800 \mathrm{~m}$ and the surface roughness amounts to $R_{\mathrm{a}}=0.83 \mu \mathrm{m}$.

The friction surfaces are examined in detail by the profilometric analysis and optical microscopy and the results of tribological tests are confirmed. This material should be used in deadwood complexes of sea transport vessels, in particular, bearings, which are cooled by seawater. speed $v=1 \mathrm{~m} / \mathrm{s}\left(I_{m}=0.05-0.07 \mathrm{mg} / \mathrm{km}\right)$ has the lowest

\section{REFERENCES}

1. C.V. Panin, L.A. Kornienko, T.N. Suan, L.R. Ivanova, M.A. Poltaranin, Procedia Eng. 113, 490 (2015).

2. A.V. Buketov, O.O. Sapronov, M.V. Brailo, Strength Mater. 46, 717 (2014).

3. A.V. Buketov, M.V. Brailo, O.S. Kobel'nyk, O.V. Akimov, Mater. Sci. 52, 25 (2016).

4. L. Du-Xin, L. Wen-Juan, X. Ying, L. Xiang-Xiang, J. Appl. Polym. Sci. 124, 4239 (2012).

5. V.O. Dzyura, P.O. Maruschak, I.M. Zakiev, A.P. Sorochak, Int. J. Eng. 30, 1170 (2017).

6. U.K. Dwivedi, N. Chand, Appl. Compos. Mater. 16, 93 (2009).

7. L.-H. Sun, Z.-G. Yang, X.-H. Li, Polym. Eng. Sci. 48, 1824 (2008).

8. A.V. Buketov, A.A. Sapronov, N.N. Buketova, M.V. Brailo, P.O. Marushak, S.V. Panin, M.Y. Amelin, Compos. Mech. Comput. Appl. An Int. J. 9, 141 (2018).

9. A.V. Buketov, O.O. Sapronov, M.V. Brailo, P.O. Maruschak, S.V. Yakushchenko, S.V. Panin, V.D. Nigalatiy, Mech. Adv. Mater. Struct. 27, 725 (2020).

10. S. Agrawal, K.K. Singh, P.K. Sarkar, Tribol. Int. 96, 217 (2016).

11. F.X. Borras, M. Bazrafshan, M.B. De Rooij, D.J. Schipper, Proceedings of the Institution of Mechanical Engineers, Part J: Journal of Engineering Tribology, 1350650120925583 (2020).

12. Y. Şahin, P. De Baets, JOM 69, 2443 (2017).

13. Y. Zhou, F. Pervin, S. Jeelani, P.K. Mallick, J. Mater. Process. 
Technol. 198, 445 (2008).

14. A. Buketov, O. Sapronov, M. Brailo, V. Aleksenko, Mater. Sci. 49, 696 (2014).

15. N.K. Myshkin, M.I. Petrokovets, A.V. Kovalev, Tribol. Int. 38, 910 (2005).
16. B. Lim, Dent. Mater. 18, 1 (2002).

17. J. Chen, Q. Guo, S. Zhang, X. Wang, X. Shao, Procedia Eng. 36, 285 (2012).

18. B. Chen, J. Wang, F. Yan, Tribol. Lett. 42, 17 (2011).

19. Z. Wang, J. Ni, D. Gao, Friction 6, 183 (2018).

\title{
Нанозаповнені антифрикційні полімерні композиційні матеріали для деталей вузлів тертя морського та річкового транспорту
}

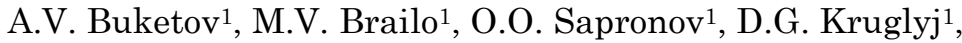 \\ E.S. Appazov ${ }^{1}$, L. Dulebová 2 K.M. Klevtsov ${ }^{1}$ \\ ${ }^{1}$ Kherson State Maritime Academy, 20, Ushakov Ave., 73003 Kherson, Ukraine \\ 2 Technical University of Košice, 1/9, Letná St., 04001 Košice, Slovak Republic
}

\begin{abstract}
Проаналізовано трибологічні властивості епоксидних композиційних матеріалів, наповнених нано- та мікродисперсними частинками та термопластиком, під впливом середовища морської води. Встановлено, що склад матеріалу, умови тертя та морське середовище суттево впливають на трибологічні властивості композитів. Вивчено трибологічні властивості розробленої епоксидної матриці, яка містить два різні затверджувачі. Доведено вдосконалення трибологічних властивостей композитів із введенням до їх складу частинок нанографіту та перліту. Запропоновано метод поліпшення антифрикційних властивостей полімерних композиційних матеріалів шляхом поєднання термореактивної матриці, заповненої нано- та мікродисперсними частинками, з термопластичними гранулами. Доведено, що трибологічні властивості епоксидно-композиційних термореактивних пластмас були покращені за рахунок додавання до їх складу гранул термопластичного наповнювача, який називається поліамід РА-6, під час тертя під впливом морської води. На основі отриманих результатів досліджень запропоновано припущення про механізм зносу епоксидних композитів з двокомпонентним бідисперсним наповнювачем. Для підтвердження отриманих результатів проведено дослідження шорсткості поверхні композитів у зоні контакту після випробування на тертя за допомогою профілометра, а також оптичного методу. Дано рекомендації щодо використання розробленого композиту з термопластичними гранулами для виготовлення підшипників ковзання.
\end{abstract}

Ключові слова: Тертя, Трибологічні властивості, Епоксидний композит, Морський та річковий транспорт. 